\title{
An Examination of Soil Microbial Communities and Litter Decomposition in Five Urban Land Uses in Metropolitan Milwaukee, WI, U.S.
}

\author{
Keith N. Turnquist, Les P. Werner, and Brian L. Sloss
}

\begin{abstract}
The process of urbanization may alter the ability of microorganisms to supply nutrients to plants. However, both the composition and structure of soil biological communities, and the extent of variation within these communities, is not clear in urban areas. Therefore, baseline information regarding the impact of urban land management practices on soil microbial communities is essential to improving individuals' ability to manage urban soils and the plants they support. This study examined soil microbial communities over five urban land uses with different degrees of urbanization in metropolitan Milwaukee, Wisconsin, U.S. The objectives were to 1) determine if differences exist in bacterial and fungal community composition, biological activity, and the soil physical and chemical environment across five urban land uses, and 2) determine if differences in the bacterial and fungal compositions compare to differences in the soil's physical and chemical characteristics. Bulk density, soil organic matter, $\mathrm{pH}$, magnesium, sodium, total nitrogen, and C:N ratio displayed significant differences between streets and forests. Microbial biomass did not differ between land uses, and the differences in bacterial and fungal community composition reflect only a small portion of the total microbial pool. The decomposition of transposed leaf litter showed significant decline in C:N ratio over time, but no statistical differences between land use were observed. The results display a highly redundant microbial assemblage, and suggest that in locations with adequate levels of soil carbon and where parent material and soil forming processes are homogeneous, urbanization and landscape management have less impact on soil microbiology than expected.

Key Words. PLFA; Soil; Soil Bacteria; Soil Fungi; Soil Microbiology; TRFLP; Urbanization; Wisconsin.
\end{abstract}

Nutrient cycling, most notably carbon (C) and nitrogen $(\mathrm{N})$, are primarily regulated by the composition, activity, and relative abundances of soil bacteria and fungi. These organisms are thought to be influenced by the type and quantity of organic inputs and the physical and chemical environment in which they live (Zak et al. 2003; Lauber et al. 2008). It is widely believed that changes to the organic inputs or the soil's physical and chemical environment will alter the composition and structure of the soil microbial community, and presumably alter the products of the processes these organisms regulate (Faeth et al. 2005; Lauber et al. 2008; Hall et al. 2009).

The urbanization of rural lands tends to alter historic vegetation patterns (Faeth et al. 2005; Nowak et al. 2007) and induce changes in the soil's physical and chemical properties (Craul et al. 1999; Scharenbroch et al. 2005). For example, the process of urbanization has been reported to alter both the quantity (i.e., tree density, Nowak et al. 2007) and composition (e.g., tree species, leaves and woody debris versus grass clippings) of organic inputs into the soil (Craul et al. 1999; Faeth et al. 2005; Scharenbroch et al. 2005). Urbanization has also been demonstrated to alter bulk density, soil aggregation and porosity, temperature and moisture regimes, and soil $\mathrm{pH}$ (Craul et al. 1999). Additionally, the by-products of industrial activity-most notably the heavy metals lead, cadmium, mercury, zinc, copper, and chromium-tend to accumulate in the soils of heavily industrialized urban areas (Fantroussi et al. 1999; Hinojosa et al. 2005; Ayansina and Oso 2006; Yang 2006; Park et al. 2010). The degree of soil alteration associated with urbanization appears to be related 
to 1) intensity of the urbanization [e.g., singlefamily residential versus city center (Pouyat et al. 2007)], 2) the extent of land management activities required to maintain the landscape in its current urban land use (Fantroussi et al. 1999; Pouyat et al. 2007), and 3) the time elapsed since the initiation of the land-use conversion (Scharenbroch et al. 2005). Generally, changes to the soils' physical and chemical properties are most pronounced in areas that support a high density of urban infrastructure (e.g., roads and buildings) or have recently undergone a significant land-use change.

The process of urbanizing and the subsequent maintenance of formerly rural landscapes are believed to negatively affect the soil biology (McDonnell et al. 1997; Kaye et al. 2005; Newbound et al. 2012; Xu et al. 2014). Unfortunately, the direct and persistent effects of urbanization on soil microbial communities remains largely unstudied when compared to the number of investigations involving the impact on the soils' chemical or physical properties. Furthermore, there are no reports within the scientific literature that define the ideal or desired structure and composition for a soil's microbial community. Consequently, urban landscape managers attempting to mitigate or correct the effects of urbanization on soils' biological communities, and the processes they regulate, lack essential baseline information upon which to make soil management decisions. Therefore, the goal of this study was to compare soil microbial communities across various urban landscapes and to identify key soil characteristics that may aid in evaluating the state of the biology in urban soils. It is hypothesized that the combination of changes in edaphic characteristics induced by the process of urbanization, associated landscape management activities, and the time elapsed since the initiating land-use conversion event will result in significant changes in the abundance, structure, and activity of the soils' microbial community. Specifically, the objectives were to 1) determine if differences exist in bacterial and fungal community composition, biological activity, and the soil physical and chemical environment across five urban land uses, and 2) determine if differences in the bacterial and fungal compositions compare to differences in the soil's physical and chemical characteristics.

\section{MATERIALS AND METHODS}

\section{Experimental Design}

Study sites were located within a $12 \mathrm{~km}$ radius in metropolitan Milwaukee, Wisconsin, U.S. The soils within the Milwaukee area are typically deep, moderately well to well drained, and slightly alkaline, consisting of fine textured loess deposits over alkaline glacial till. Common soil series in this area include Morley, Blount, Varna, and Elliot; however, a majority of the soil in the City of Milwaukee has not been classified as a result of anthropogenic influences (Soil Survey Staff).

The urban land-use designations in this study were urban street side terraces [Streets (ST)], new ( $<5$ years since development) residential landscapes receiving intensive management [New Managed (NM)], old ( $>25$ years since development) residential landscapes receiving intensive management [Old Managed (OM)], old residential landscapes receiving minimal management [Old Unmanaged (OU)], and forested lands [Forests (FR)]. Intensively managed study sites received regular fertilizer applications and pesticide treatments over the last 25 years $(\mathrm{OM})$ or 5 years (NM) (pers. comm.: Nick Crawford, Crawford Tree and Landscaping, April 2009), whereas the unmanaged properties have no record of receiving fertilizer or pesticide applications over the past 25 years (pers. comm.: property owners, April 2009). Based on exposure to anthropogenic influences (management level, vehicular traffic loads, and housing densities) and previous findings that soils recover from disturbances over time (Scharenbroch et al. 2005), the order of land-use designations from most- to least-urbanized, in this study, was assumed to be: $\mathrm{ST}>\mathrm{NM}>\mathrm{OM}>$ $\mathrm{OU}>\mathrm{FR}$. The vegetative communities in all locations, with the exception of FR sites, consisted of turfgrass areas with landscape trees of various species. The FR sites had mixed hardwood vegetation dominated by Quercus sp. >25-years-old with a leaf litter surface layer devoid of turfgrass.

Five urban study sites were randomly selected for each land use from a pool of potential locations, resulting in 25 urban sites. Each study site was subdivided into $25 \mathrm{~m}^{2}$ soil sampling areas. Within each study site, three soil cores $(2.5 \mathrm{~cm}$ $\times 25 \mathrm{~cm}$ ) were removed from the near center 
of five randomly selected sampling areas and homogenized into one representative soil sample. Approximately half of the homogenized soil samples were placed in paper bags, air dried, passed through a $2 \mathrm{~mm}$ sieve, and stored at room temperature until physical and chemical analysis. The remaining soil was immediately placed on ice, frozen within 12 hours, and stored at $-20^{\circ} \mathrm{C}$ prior to biological analysis.

\section{Physical and Chemical Soil Analysis}

Physical characteristics measured for each site included: percent sand, silt, and clay measured by the hydrometer method (Gee and Bauder 1986); soil organic matter (SOM) content (percent loss on ignition, Kalra and Maynard 1991); percent volumetric water content at field capacity (pressure plate technique at one third bar, Gardner 1986); and bulk density as measured by averaging two $68.7 \mathrm{~cm}^{3}$ oven-dried soil samples (Blake and Hartage 1986) independently collected with an ICT International model 0200 Soil Bulk Density Sampler (ICT International, Australia) at two randomly selected undisturbed locations in each study site. Chemical analyses consisted of total carbon (C), and total nitrogen $(\mathrm{N})$ as measured on a CE 2000 Carbon nitrogen analyzer (Carlo Erba), 2:1 water:soil pH (electrode), extractable phosphorus (Bray), ammonium acetate extracted calcium $(\mathrm{Ca})$, magnesium $(\mathrm{Mg})$, potassium $(\mathrm{K})$, sodium $(\mathrm{Na})$, and cation exchange capacity (CEC), by summation of the base cations $\mathrm{Ca}, \mathrm{Mg}, \mathrm{K}$, and $\mathrm{Na}$.

\section{Molecular Community Fingerprint Analysis with TRFLP}

Terminal restriction fragment length polymorphism (TRFLP) was used to profile the bacterial and fungal communities (Liu et al. 1997). All molecular analyses were performed in the University of Wisconsin-Stevens Point Molecular Conservation Genetics Laboratory (MCGL). Microbial DNA was extracted from $0.25 \mathrm{~g}$ of soil using a variation of the modified Burgmann method (Thakuria et al. 2008). The variation consisted of replacing the final polyvinylpolypyrrolidone spin column with a modified gel purification method according to Zhang et al. (2009).
Reaction mixtures for bacterial $16 \mathrm{~S}$ rDNA PCR amplification contained $1 \mu$ template DNA, $1 \times$ Taq buffer (New England Biolabs, Ipswich, Massachusetts, U.S.), $600 \mu \mathrm{M}$ dNTPs, $3.0 \mathrm{mM}$ $\mathrm{MgCl}_{2}, 0.25 \mathrm{mg}$ bovine serum albumin (BSA), $150 \mu \mathrm{M}$ each primer, and 2.5 U Taq DNA polymerase (New England Biolabs) in a final volume of $50 \mu \mathrm{l}$. The primers were 6-FAM labeled $8 \mathrm{f}$ (6FAM-AGAGTTTGATCCTGGCTCAG) and 926r (CCGTCAAATCCTTTRAGTTT) (Hackl et al. 2004). Bacterial PCR conditions consisted of a 5 -min hot start at $95^{\circ} \mathrm{C}$, followed by 25 cycles of $95^{\circ} \mathrm{C} / 1 \mathrm{~min}, 53^{\circ} \mathrm{C} / 1 \mathrm{~min}, 72^{\circ} \mathrm{C} / 1$ min with a final extension of $72^{\circ} \mathrm{C} / 15 \mathrm{~min}$. For fungal $18 \mathrm{~s}$ rDNA amplification, the PCR reaction contained $1 \mu \mathrm{l}$ template DNA, $1 \times$ Taq buffer (New England Biolabs), $600 \mu \mathrm{M}$ dNTPs, $2.0 \mathrm{mM} \mathrm{MgCl}, 0.25 \mathrm{mg}$ BSA, $100 \mu \mathrm{M}$ each primer, and $2.5 \mathrm{U}$ Taq DNA polymerase (New England Biolabs) in a final volume of $50 \mu \mathrm{l}$. The primers were PET labeled fun18S1 (PETCCATGCATGTTAAGTWTAA) and fung5 (GTAAAAGTCCTGGTTCCCC) (Anderson and Cairney 2004). Fungal PCR conditions consisted of a 5 -min hot start at $95^{\circ} \mathrm{C}$, followed by 35 cycles of $95^{\circ} \mathrm{C} / 30 \mathrm{sec}, 53^{\circ} \mathrm{C} / 30 \mathrm{sec}, 72^{\circ} \mathrm{C} / 1$ min with a final extension of $72^{\circ} \mathrm{C} / 15 \mathrm{~min}$. Three PCRs of each sample were performed on a GeneAmp 9700 (Applied Biosystems, Foster City, California, U.S.), and the resulting products were pooled to minimize bias. The pooled products were cleaned and concentrated using a DNA Clean \& Concentrator25 Kit (Zymo Research, Irvine, California, U.S.) following the manufacturer's protocol.

Multiple single digests of the concentrated bacterial and fungal PCR products were completed using $10 \mathrm{U}$ of restriction enzyme for two hours at $37^{\circ} \mathrm{C}$. The bacterial products were digested with HhaI, MspI, and RsaI (New England Biolabs) and renamed B1, B2, and B3, respectively. Similarly, fungal PCR products were digested with AluI, MspI, and RsaI (New England Biolabs) and renamed F1, F2, and F3, respectively. Terminal restriction fragments (T-RF) were visualized using a 3730xl Genetic Analyzer (Applied Biosystems) with LIZ $^{\mathrm{m}} 1200$ internal size standard (Applied Biosystems). Fragments were sized using Genemapper v4.0 analysis 
software (Applied Biosystems) and a custom $2 \mathrm{bp}$ binning panel (Rees et al. 2004) with a minimum peak height detection of 50 fluorescent units.

\section{Microbial Biomass and Microbial Community Lipid Analysis (PLFA/FAME)}

Lipid analyses were completed using a hybrid procedure of phospholipid fatty acid (PLFA) and fatty acid methyl ester (FAME) analysis (Balser 2001) at the University of Wisconsin-Madison. Approximately $3.0 \mathrm{~g}$ of milled, freeze-dried soil was extracted and analyzed according to Waldrop and Firestone (2004). The bacterial fatty acid standards 9:0 (nonanoic methyl ester) and 19:0 (nonadecanoic methyl ester) (Sigma, St. Louis, Missouri, U.S.) with MIDI peak identification software (MIDI, Newark, Delaware, U.S.) were used to identify peaks. Fatty acids were excluded if present in less than 3 samples or if less than $0.5 \mathrm{~mol} \%$.

\section{Litter Decomposition}

Fifteen in situ litter decomposition bags containing approximately $1.0 \mathrm{~g}$ of air-dried white oak (Quercus alba) leaves were buried at randomly selected locations in each study site. The litter bags were constructed of gray $1.0 \mathrm{~mm}$ fiberglass screen $(25 \mathrm{~cm} \times 20 \mathrm{~cm})$ and inserted vertically in the upper $25 \mathrm{~cm}$ of the soil profile. Prior to installation, approximately $5 \mathrm{mg}$ of leaf tissue was removed from each litter bag and analyzed for initial total $\mathrm{C}$, total $\mathrm{N}$, and $\mathrm{C}: \mathrm{N}$ ratio using an NC 2100 Soil analyzer (Alantech, Atlanta, Georgia, U.S.) with Clarity 6.12.2006 software (2006 DataApex Ltd, Czech Republic). Three buried litter decomposition bags from each property were removed $10,30,60,90$, and 120 days after installation. The bags were washed in deionized water, to remove soil particles, and air dried. The remaining leaf material was pulverized and analyzed for total $\mathrm{C}$, total $\mathrm{N}$, and $\mathrm{C}: \mathrm{N}$ ratio. Between sampling period changes in total $\mathrm{C}$, total $\mathrm{N}$, and $\mathrm{C}: \mathrm{N}$ ratio of transposed litter were analyzed using repeated measures ANOVA in statistical analysis software (SAS v9.2, Cary, North Carolina, U.S.). Differences among land uses within a sample period were analyzed in SAS using ANOVA with Duncan's multiple range test (Duncan's MRT).

\section{Statistical Analysis}

One-way analysis of variance (ANOVA, $\alpha=0.05$ ) and Duncan's MRT were conducted using SAS to compare soil physical and chemical properties among land uses. All physical and chemical attributes were normalized according to Clarke and Gorley (2006). The physical and chemical properties of each sample were compared with a Euclidian distance matrix using Plymouth Routines in Multivariate Ecological Research v6 (PRIMER v6, Lutton, UK) (Clarke and Gorley 2006). Analysis of similarities (ANOSIM) and non-metric multi-dimensional scaling (MDS) (2D stress limit of $<0.20$ ) with cluster overlay (PRIMER v6) were used to make inferences regarding differences in the edaphic properties of the soils among land uses. Pairwise land-use comparisons were evaluated on the edaphic properties if the global $\mathrm{R}$ value was significant ( $\alpha$ $=0.05,999$ permutations, Clarke and Warwick 2001). Pairwise $R$ values below 0.50 indicated edaphic variables within the land-use categories were not separated, values between 0.50 and 0.70 were overlapping, and values above 0.70 were well separated (Clarke and Warwick 2001).

Estimates of total microbial biomass [sum of total microbial lipids (Balser 2001)] in each land use were compared using a one-way ANOVA $(\alpha=$ 0.05). Individual lipids were standardized by dividing the respective lipid abundances ( $\mu \mathrm{mol} / \mathrm{g}$ soil) by the total lipid abundance within the sample (Balser 2001). Individual peaks within the TRFLP bacterial and fungal profiles were standardized by dividing by the sum of all peak heights within that profile (Rees et al. 2004). Simpson diversity, Shannon diversity, Pielou's evenness, and Margalef species richness (Clarke and Gorley 2006) were calculated from the standardized TRFLP and PLFA/FAME profiles (PRIMER v6). Oneway ANOVA $(\alpha=0.05)$ and Tukey's Honestly Significant Difference (Tukey's HSD) were used to evaluate differences in biodiversity measures among land uses for the samples. For multivariate analysis, standardized TRFLP and PLFA/FAME profiles were square-root transformed and analyzed with a Bray-Curtis similarity matrix using ANOSIM and MDS (2D stress $<0.20)$ with cluster overlay in PRIMER v6 (Rees et al. 2004). 


\section{RESULTS}

\section{Soil Physical and Chemical Properties}

Land use had a significant effect on two physi$\mathrm{cal}$ and seven chemical measurements. The bulk density of ST and NM were $45 \%-50 \%$ higher than FR $(P<0.001$, Table 1). Soil organic matter in the ST and NM were $40 \%$ lower than OU and FR $(P=0.005$, Table 1$)$. Soil $\mathrm{pH}(P<0.001)$, total $\mathrm{N}(P=0.015)$, extractable $\mathrm{K}(P=0.006), \mathrm{Mg}$ $(P<0.001), \mathrm{Na}(P<0.001)$, and $\mathrm{P}(P=0.026)$
(Table 2) were all significant. Soil pH decreased consistently from ST to FR (Table 2) where the ST and NM land uses differed from the other land uses. Conversely, total $\mathrm{N}$ and $\mathrm{Mg}$ increased from ST to FR and extractable Na was $230 \%$ or higher in ST than all other land uses (Table 2). The combined edaphic characteristics of the ST were most similar to NM, and were well separated from those of the OM, OU, and FR (Table 3; Figure 1). The remaining land-use comparisons were either overlapping, or not well separated.

Table 1. Mean values \pm standard error $(n=5)$ for physical properties of soils collected on May 17 th and 18 th, 2009 from: street side terraces (ST), new managed (NM), old managed (OM), old unmanaged (OU), and forest (FR) properties in metropolitan Milwaukee, Wisconsin, U.S. Variables with significant ANOVA $(\alpha=0.05, n=5)$ were analyzed with Duncan's MRT; the differences among the land uses are indicated by lowercase letters.

\begin{tabular}{|c|c|c|c|c|c|c|c|}
\hline Land use & $\begin{array}{l}\text { Bulk density } \\
\left(\mathrm{g} / \mathrm{cm}^{3}\right)\end{array}$ & $\begin{array}{l}\text { Soil organic } \\
\text { matter (\%LOI) }\end{array}$ & $\begin{array}{l}\text { CEC } \\
(\mathrm{mmol} / \mathrm{kg})\end{array}$ & $\begin{array}{l}\text { Water at field } \\
\text { capacity }(\%)\end{array}$ & $\begin{array}{l}\text { Sand } \\
(\%)\end{array}$ & $\begin{array}{l}\text { Silt } \\
(\%)\end{array}$ & $\begin{array}{l}\text { Clay } \\
(\%)\end{array}$ \\
\hline ST & $1.51 \pm 0.03 \mathrm{a}$ & $6 \pm 0.6 \mathrm{a}$ & $207 \pm 5.0 \mathrm{a}$ & $21 \pm 1 \mathrm{a}$ & $39 \pm 2 a$ & $42 \pm 1 \mathrm{a}$ & $20 \pm 3 a$ \\
\hline NM & $1.41 \pm 0.07 \mathrm{a}$ & $6 \pm 0.5 \mathrm{a}$ & $217 \pm 5.8 \mathrm{a}$ & $23 \pm 2 a$ & $35 \pm 5 a$ & $43 \pm 3 a$ & $23 \pm 2 a$ \\
\hline OM & $1.11 \pm 0.03 b$ & $8 \pm 0.4 \mathrm{ab}$ & $211 \pm 13.3 \mathrm{a}$ & $31 \pm 3 a$ & $28 \pm 4 a$ & $45 \pm 7 \mathrm{a}$ & $28 \pm 7 a$ \\
\hline $\mathrm{OU}$ & $1.09 \pm 0.05 b$ & $10 \pm 1.0 \mathrm{~b}$ & $218 \pm 16.2 \mathrm{a}$ & $28 \pm 3 a$ & $34 \pm 31 a$ & $43 \pm 5 a$ & $24 \pm 5 \mathrm{a}$ \\
\hline FR & $0.97 \pm 0.08 b$ & $10 \pm 1.6 \mathrm{~b}$ & $199 \pm 19.2 \mathrm{a}$ & $30 \pm 4 a$ & $35 \pm 10 a$ & $54 \pm 6 a$ & $11 \pm 4 \mathrm{a}$ \\
\hline
\end{tabular}

Table 2. Mean values \pm standard error $(n=5)$ for chemical properties of soils collected on 17 and May 2009 from: street side terraces (ST), new managed (NM), old managed (OM), old unmanaged (OU), and forest (FR) properties in metropolitan Milwaukee, Wisconsin, U.S. Variables with significant ANOVA $(\alpha=0.05, n=5)$ were analyzed with Duncan's MRT; the differences among the land uses are indicated by lowercase letters.

\begin{tabular}{|c|c|c|c|c|c|c|c|c|}
\hline Land use & $\begin{array}{l}\mathrm{pH} \\
(\mathrm{mg} / \mathrm{kg})\end{array}$ & $\begin{array}{l}\mathrm{P} \\
(\mathrm{mg} / \mathrm{kg})\end{array}$ & $\begin{array}{l}\mathrm{Ca} \\
(\mathrm{mg} / \mathrm{kg})\end{array}$ & $\begin{array}{l}\mathrm{K} \\
(\mathrm{mg} / \mathrm{kg})\end{array}$ & $\begin{array}{l}\mathrm{Mg} \\
(\mathrm{mg} / \mathrm{kg})\end{array}$ & $\begin{array}{l}\mathrm{Na} \\
(\mathrm{mg} / \mathrm{kg})\end{array}$ & $\begin{array}{l}\mathrm{C} \\
(\mathrm{g} / 100 \mathrm{~g})\end{array}$ & $\begin{array}{l}\mathrm{N} \\
(\mathrm{g} / 100 \mathrm{~g})\end{array}$ \\
\hline ST & $8.3 \pm 0.2 \mathrm{a}$ & $1.7 \pm 0.7 \mathrm{a}$ & $3365 \pm 95 a$ & $71 \pm 9 c$ & $311 \pm 16 a$ & $280 \pm 62 a$ & $5.0 \pm 0.3 \mathrm{a}$ & $0.15 \pm 0.03 a$ \\
\hline NM & $8.0 \pm 0.0 \mathrm{ab}$ & $7.2 \pm 0.7 \mathrm{a}$ & $3441 \pm 99 a$ & $112 \pm 10 \mathrm{bc}$ & $484 \pm 31 b$ & $66 \pm 25 b$ & $4.4 \pm 0.6 \mathrm{a}$ & $0.18 \pm 0.02 \mathrm{a}$ \\
\hline OM & $7.8 \pm 0.1 b c$ & $4.3 \pm 1.2 \mathrm{a}$ & $3228 \pm 257 a$ & $137 \pm 7 \mathrm{ab}$ & $520 \pm 14 b c$ & $84 \pm 47 b$ & $4.2 \pm 0.5 \mathrm{a}$ & $0.23 \pm 0.03 \mathrm{ab}$ \\
\hline $\mathrm{OU}$ & $7.7 \pm 0.1 \mathrm{~cd}$ & $18.0 \pm 7.1 \mathrm{~b}$ & $3328 \pm 318 a$ & $162 \pm 19 a$ & $557 \pm 30 b c$ & $38 \pm 13 b$ & $4.9 \pm 0.7 \mathrm{a}$ & $0.34 \pm 0.05 b$ \\
\hline FR & $7.4 \pm 0.1 \mathrm{~d}$ & $6.2 \pm 1.9 \mathrm{a}$ & $2966 \pm 324 a$ & $90 \pm 27 b c$ & $575 \pm 29 c$ & $41 \pm 10 b$ & $4.1 \pm 0.7 \mathrm{a}$ & $0.33 \pm 0.06 \mathrm{~b}$ \\
\hline
\end{tabular}

Table 3. Analysis of similarity (ANOSIM) of edaphic properties, bacterial (B1, B2, B3) and fungal (F1, F2, F3) communities, and total microbial community lipids between different soils collected on 17 and 18 May 2009 from: street side terraces (ST), new managed (NM), old managed (OM), old unmanaged (OU), and forest (FR) properties in metropolitan Milwaukee, Wisconsin, U.S. The global R values (999 permutations) are given with the edaphic character, each bacterial community, each fungal community, and total microbial lipid community. Each $R$ value is presented for both the global and pairwise sections. High $\mathbf{R}$ values indicate a greater degree of land-use separation. Land uses with $\mathrm{R}$ values $<0.5$ are considered not separated, $R$ values between 0.5 and 0.7 are overlapping, and $R$ values over 0.7 are well separated.

\begin{tabular}{|c|c|c|c|c|c|c|c|c|}
\hline & Edaphic & B1 & B2 & B3 & $\mathrm{F} 1$ & $\mathrm{~F} 2$ & $\mathrm{~F} 3$ & Total lipids \\
\hline $\begin{array}{l}\text { Global R } \\
\text { (P-value) }\end{array}$ & $\begin{array}{l}0.417 \\
(0.001)\end{array}$ & $\begin{array}{l}0.461 \\
(0.001)\end{array}$ & $\begin{array}{l}0.439 \\
(0.001)\end{array}$ & $\begin{array}{l}0.269 \\
(0.001)\end{array}$ & $\begin{array}{l}0.371 \\
(0.001)\end{array}$ & $\begin{array}{l}0.200 \\
(0.001)\end{array}$ & $\begin{array}{l}0.187 \\
(0.014)\end{array}$ & $\begin{array}{l}0.359 \\
(0.001)\end{array}$ \\
\hline NM, OU & $0.392(0.008)$ & $0.292(0.008)$ & $0.113(0.222)$ & $0.068(0.286)$ & $0.500(0.008)$ & $-0.016(0.595)$ & $0.140(0.183)$ & $0.213(0.159)$ \\
\hline $\mathrm{NM}, \mathrm{OM}$ & $0.228(0.056)$ & $0.828(0.008)$ & $0.750(0.008)$ & $0.340(0.048)$ & $0.836(0.008)$ & $0.092(0.167)$ & $0.184(0.095)$ & $0.325(0.103)$ \\
\hline NM, FR & $0.564(0.008)$ & $0.848(0.008)$ & $0.763(0.008)$ & $0.576(0.008)$ & $0.772(0.008)$ & $0.520(0.008)$ & $0.388(0.016)$ & $0.513(0.016)$ \\
\hline NM, ST & $0.540(0.008)$ & $0.431(0.016)$ & $0.281(0.057)$ & $0.275(0.071)$ & $0.650(0.008)$ & $0.050(0.365)$ & $-0.006(0.468)$ & $0.169(0.167)$ \\
\hline OU, OM & $0.016(0.381)$ & $0.280(0.040)$ & $0.400(0.008)$ & $0.052(0.317)$ & $-0.044(0.563)$ & $0.176(0.040)$ & $-0.048(0.603)$ & $0.420(0.024)$ \\
\hline OU, FR & $0.036(0.365)$ & $0.248(0.056)$ & $0.408(0.008)$ & $0.288(0.016)$ & $-0.040(0.611)$ & $0.196(0.063)$ & $0.160(0.159)$ & $0.348(0.024)$ \\
\hline OU, ST & $0.812(0.008)$ & $0.213(0.087)$ & $0.156(0.190)$ & $0.138(0.238)$ & $0.119(0.214)$ & $0.031(0.397)$ & $0.244(0.103)$ & $0.468(0.016)$ \\
\hline OM, FR & $0.200(0.063)$ & $0.764(0.008)$ & $0.892(0.008)$ & $0.160(0.167)$ & $0.200(0.087)$ & $0.384(0.024)$ & $0.248(0.048)$ & $0.136(0.151)$ \\
\hline OM, ST & $0.812(0.008)$ & $0.631(0.008)$ & $0.538(0.008)$ & $0.431(0.008)$ & $0.244(0.079)$ & $0.325(0.048)$ & $0.275(0.040)$ & $0.556(0.016)$ \\
\hline FR, ST & $0.764(0.008)$ & $0.606(0.008)$ & $0.594(0.008)$ & $0.506(0.008)$ & $0.438(0.008)$ & $0.413(0.016)$ & $0.431(0.056)$ & $0.680(0.008)$ \\
\hline
\end{tabular}




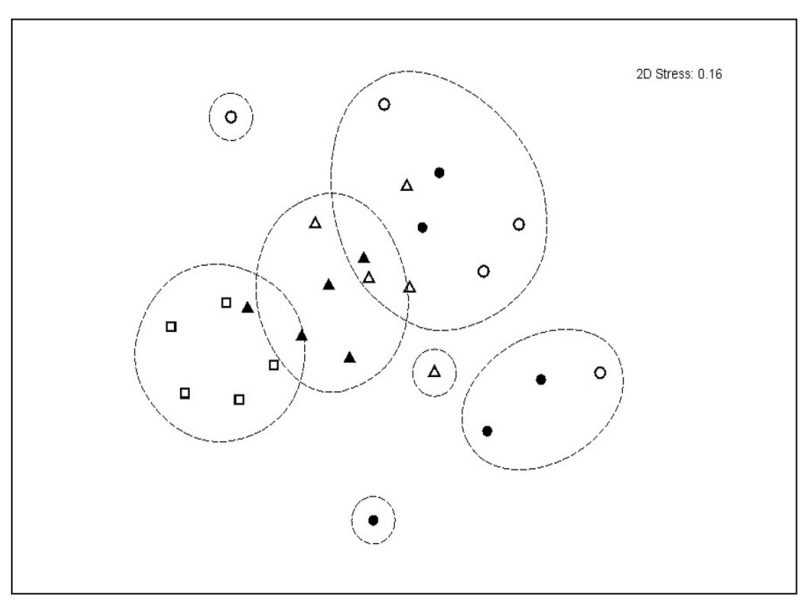

Figure 1. The 2-D MDS plot created from the edaphic variables measured from soils collected on 17 and 18 May 2009 from: street side terraces $(\square)$, new managed ( $\Delta$ ), old managed $(\Delta)$, old unmanaged $(\bullet)$, and forest $(O)$ properties in metropolitan Milwaukee, Wisconsin, U.S. Each sample property is represented by its land use. The dashed outlines indicate groupings created from a Euclidian distance cluster diagram (distance 4).

\section{Analysis of Bacterial Communities}

The intensity of urbanization had little effect on biodiversity within the bacterial community. Eight of the twelve biodiversity comparisons were insignificant (data not shown); however, FR had higher average richness and Shannon diversity than OU. Differences in the bacterial community profiles among the land uses were detected with ANOSIM and MDS. The global $\mathrm{R}$ values were all significant ( $P=0.001)$ but generally low for all three bacterial profiles, ranging from 0.269 (B3) and 0.461 (B1). Pairwise comparisons within the $\mathrm{B} 1$ and $\mathrm{B} 2$ profiles indicated bacterial communities in FR, OM, and NM are well separated from one another $(\mathrm{R}>0.70)$ (Table $3)$. However, the distinctive clusters represented by the NM, OM, and FR profiles were grouped in close proximity to one another, suggesting large-scale similarities exist among these communities (Figure 2).

\section{Analysis of Fungal Communities}

No consistent land-use effects on fungal diversity indices were observed among all three fungal profiles. However, increased urbanization appeared to decrease richness. There were also significant differences in the diversity of seven of the twelve fungal land-use comparisons (data not shown). Specifically, ST had lower average fungal richness, evenness, Shannon diversity, and Simpson diversity than all other land uses in the F1 profiles. In the F2 profiles, OU had lower richness than FR. In the F3 profiles, ST had lower richness than $\mathrm{OM}$ and FR. The ANOSIM global $\mathrm{R}$ values were all significant $(P$ $\leq 0.014)$, but low $(\mathrm{F} 1=0.371, \mathrm{~F} 2=0.200$, and $\mathrm{F} 3=$ 0.187 ). The F1 fungal community profiles showed the NM sites were well separated from the OM and FR sites, and overlapped with the OU and ST profiles (Table 3). The separations between NM and the other land uses were the product of highly similar fungal communities within the NM sites (Figure 2). All other comparisons were not significant.

\section{PLFA/FAME Estimates of Microbial Biomass and Community Analysis}

Three of the four biodiversity indices revealed significant differences among land uses (data not shown) with ST resulting in lower evenness, Shannon diversity, and Simpson diversity than FR and OM. However, total microbial biomass did not differ significantly $(P=0.579)$ among the land uses. The global $\mathrm{R}$ value $(0.359)$ was significant $(P=$ 0.001 ) but low (Table 3). Post hoc analysis indicated a high degree of variability within and between the land uses, resulting in land-use community profiles that were not well separated $(\mathrm{R} \leq 0.680)$. The MDS (Figure 3) was consistent with the ANOSIM results.

\section{Litterbag Decomposition Analysis}

The biological decomposition of the transposed leaf litter was consistent in all land uses. Over time, the $\mathrm{C}: \mathrm{N}$ ratio of transposed leaf litter declined significantly $(P=0.001)$ in all land uses, with an average C:N ratio across all sites following $0-$, 10-, 30-, 60-, 90-, and 120-day incubation of 66.80, 52.72, 43.35, $37.51,34.67$, and 34.49 , respectively. The declines in $\mathrm{C}: \mathrm{N}$ ratio, however, did not differ among land uses in any of the sampling periods, where $P=0.649$, $0.521,0.524,0.116$, and 0.097 for the 10-, 30-, 60-, 90-, and 120-day sampling periods, respectively.

\section{DISCUSSION}

The detected differences in microbial communities among the land uses were not consistent across all TRFLP or lipid community profiles, and tended to be most pronounced in comparisons between the least (forest) and the most (street) urbanized landscapes. Regardless, even at the extremes of human 
influence there remained a great deal of similarity among the TRFLP-generated bacterial, fungal profiles, and FAME/PLFA microbial community profiles. Consequently, the composition of the bacterial and fungal communities did not appear to be substantially altered by the degree of urbanization or the intensity of landscape management. These find- ings are consistent with those of Girvan et al. (2003), Kaye et al. (2005), and Newbound et al. (2012), who also observed a high degree of similarity in the composition of bacterial assemblages from landscapes with different land management histories, but were within close geographic proximity to one another with similar underlying soil characteristics

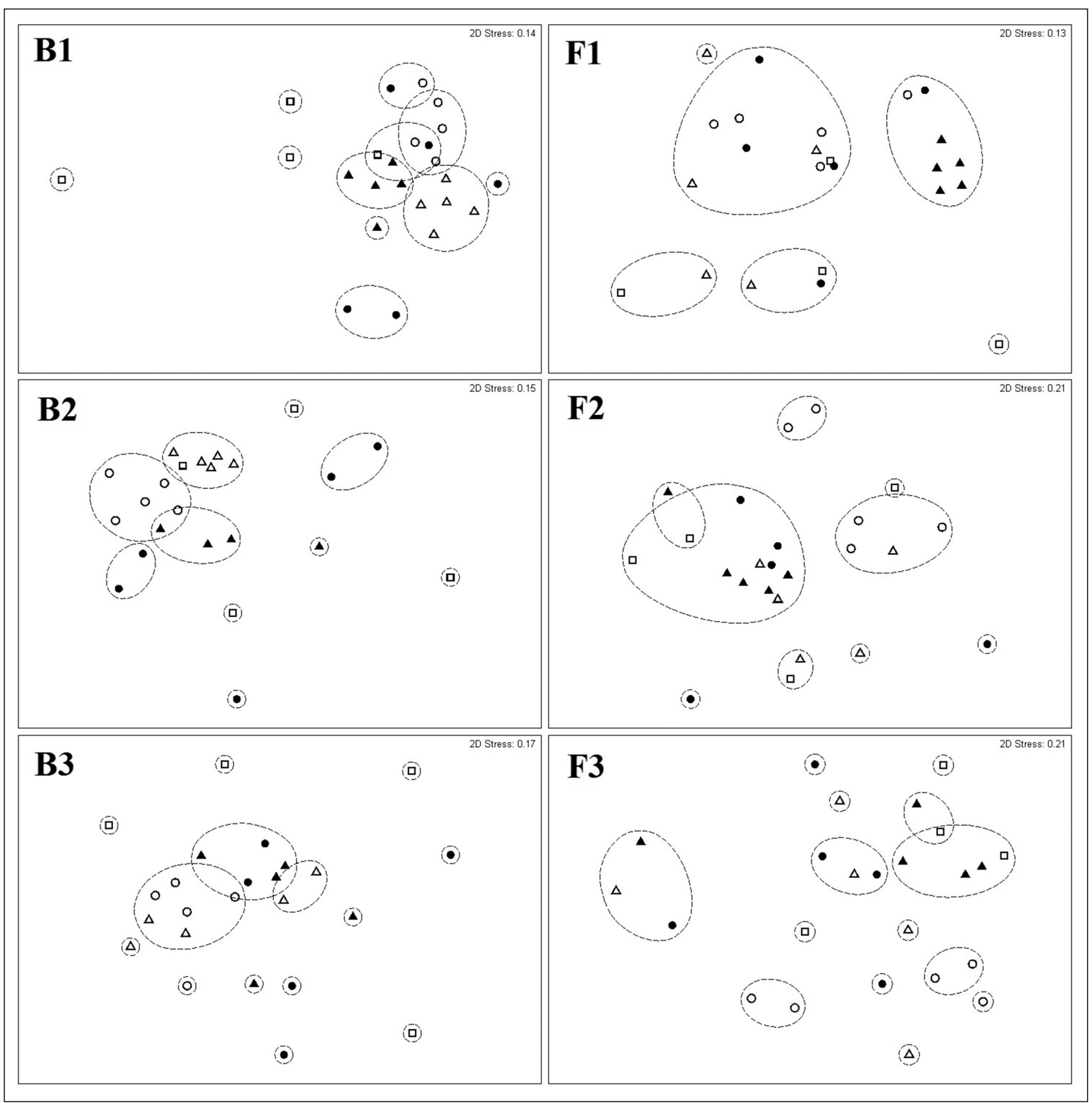

Figure 2. The 2-D MDS plots from the TRFLP bacterial communities B1, B2, and B3, and fungal communities F1, F2, and F3 as measured from soils collected on 17 and 18 May 2009 from: street side terraces ( $\square$ ), new managed ( $\Delta$ ), old managed $(\Delta)$, old unmanaged $(\bullet)$, and forest $(O)$ properties in metropolitan Milwaukee, Wisconsin, U.S. Each sample property is represented by its land use. The outlined circles indicate groupings with $65 \%$ similar bacterial or fungal populations created from a Bray-Curtis similarity cluster diagram in PRIMER v6. 


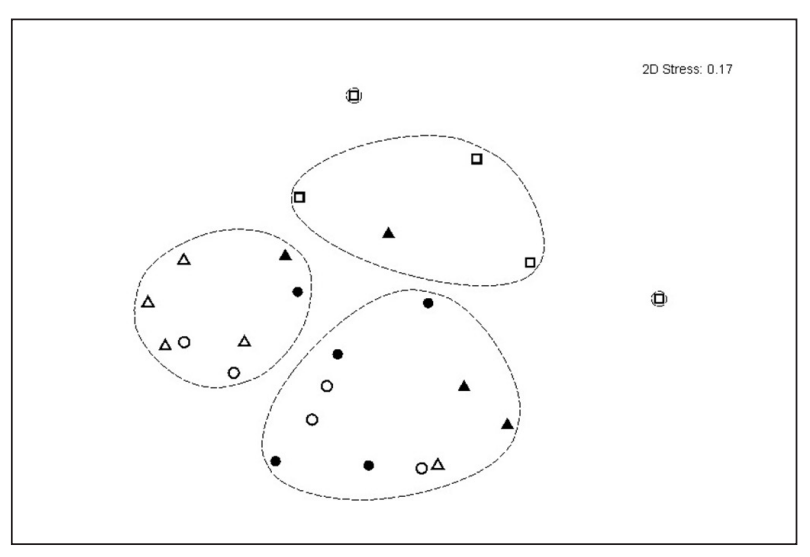

Figure 3. The 2-D MDS plot created from the total microbial community as analyzed by PLFA/FAME from soils collected on 17 and 18 May 2009 from: street side terraces ( $\square$ ), new managed $(\Delta)$, old managed $(\Delta)$, old unmanaged $(\bullet)$, and forest $(O)$ properties in metropolitan Milwaukee, Wisconsin, U.S. Each sample property is represented by its land use. The outlined circles indicate groupings with $80 \%$ similar microbial communities created from a Bray-Curtis similarity cluster diagram in PRIMER v6.

and origins. Each site in the present study was also located in a small geographic region with similar soil-forming processes and climatic regime. This resulted in limited soil texture differences (i.e., percent sand, silt, and clay) and no change in soil water-holding capacity. The strength of the assertion that geographic proximity and soil-forming factors strongly regulate the composition of soil microbial communities is reinforced by $\mathrm{Xu}$ et al. (2014), who examined the composition of soil microbial communities in urban parks within 16 Chinese cities that encompassed a wide distribution of latitudes and longitudes. The authors concluded that geographic location and the corresponding differences in temperature and precipitation, in addition to soil $\mathrm{pH}$, better explained the variability in microbial community structure than urbanization. In this study, researchers observed reductions in SOM, total $\mathrm{N}$, elevated soil $\mathrm{pH}$, bulk density, and extractable $\mathrm{Na}$ with increasing urbanization, all of which are similar to the results reported by McDonnell et al. (1997) and Scharenbroch et al. (2005). Individually and collectively, these conditions have been demonstrated to alter microbial community profiles (Balser 2001; Lauber et al. 2008; Rousk et al. 2010; Xu et al. 2014) and/or biological functioning (Rietz and Haynes 2003; Pavao-Zuckerman and Coleman 2007; Hall et al. 2009; Rousk et al. 2009).
The observed differences in $\mathrm{pH}$ and sodium in the Milwaukee sites were likely too small to have a significant influence on the native microbial communities. Rousk et al. (2010) identified $\mathrm{pH}$ as an influence to the relative abundance and diversities of soil bacteria; however, the influential range of values (4 to 8 ) was far greater than those observed in the Milwaukee sites [7.4 to 8.2 (Table 2)]. Similarly, Högberg et al. (2007), Lauber et al. (2008), and Singh et al. (2008) correlated $\mathrm{pH}$ to bacterial communities, but again the $\mathrm{pH}$ values $(<5)$ were acidic. Acidic soils with $\mathrm{pH}$ of 4.5 and below have been documented as having an inhibitory influence on microbial function (Rousk et al. 2009); however, this is very different than the alkaline Milwaukee soils used in the present study. The elevated sodium levels measured in the street-side locations is attributed to winter salt additions on all area roads (pers. comm.: R. Krouse, City of Milwaukee). Omar et al. (1994) observed a decrease in bacterial and fungal counts only after the addition of more than $5 \% \mathrm{NaCl}$ to a garden soil. Despite the significant increase in $\mathrm{Na}$ levels observed in the Milwaukee street-side locations, the $5.8 \%$ exchangeable $\mathrm{Na}$ percentage was far less than a $5 \%$ total $\mathrm{NaCl}$, and is not high enough to interfere with the structure and function of the microbial communities.

Furthermore, the differences detected in soil organic matter, total $\mathrm{N}$, and bulk densities also resulted in a minimal influence on the microbial communities. There is evidence suggesting that vegetative community differences observed in urban areas result in reduced SOM and increased soil bulk densities (Scharenbroch et al. 2005; Scharenbroch and Lloyd 2006; Nowak et al. 2007). Similarly, reductions in soil organic matter were observed in areas with greater human influence; however, the reduction in SOM did not reduce total soil carbon. Differences in the amount and composition of soil carbon substrates can initiate a shift in microbial biomass, community composition, and microbial activity (Goldfarb et al. 2011). However, if there are limited changes to soil carbon additions, a sustainable and generally homogeneous carbon substrate will be maintained in the soil. Ultimately, if resources (carbon substrates) are not limiting and selective pressures are low, microbial diversity would remain unchanged, and a redundant microbial community would result (Zhou et al. 2002). 
In general, variations to microbial communities appear to be more pronounced when urbanization occurs in native landscapes, where primary production is severely limited by extremes in temperature and moisture (Xu et al. 2014). Native limitations to primary production and plant communities are often overcome during the creation and management of urbanized landscapes through irrigation and fertilization; thereby stimulating a buildup of soil carbon that largely differs from the native landscape. The size and quality of the soil carbon pool, in particular, has been shown to influence both microbial biomass and ecosystem functioning, particularly nitrogen mineralization (Kaye et al. 2005). Kaye et al. (2005) detected limited differences in soil microbial assemblages attributed to the increased urbanization; however, they additionally observed statistically higher microbial biomass in urban landscapes relative to the surrounding agricultural areas. They attributed this increase in microbial biomass to elevated soil carbon storage and enhanced carbon cycling rates in the urban landscape as compared to agricultural sites. Contrary to Kaye et al. (2005), the present study found no changes in soil microbial biomass or total carbon across the different land uses; therefore, it would appear the statistical differences observed in SOM are not of sufficient magnitude to generate a significant difference in soil carbon or large scale shifts in the microbial composition, and likely did not limit the growth of the microbial community. Within the land-use categories with the highest levels of urbanization in this study, the soil carbon pools and accompanying chemical and physical environments are capable of supporting a high level of microbial diversity and potentially, associated ecological functioning; as verified by statistically similar outcomes of in situ litter decomposition.

Despite being a coarse measure of microbial activity, the comparable degradation of a moderately difficult to decompose organic substrate (Quercus alba leaves) suggests the biological communities in the different urban areas have a comparable capacity to decompose organic material. Although bulk densities were elevated in the highly urbanized soils, any oxygen deficiencies associated with high bulk densities did not limit microbial activity in the degradation of the transposed leaf litter; this indicated the presence of a potentially resilient microbial assemblage. Furthermore, using the forested land use as a model for a sustainably functioning soil, the similarity in litter decomposition suggests the microbial communities in the different Milwaukee landscapes is similar in activity to that of the area forests. Therefore, because there were no differences in the observed microbial activity and biomass, and only subtle changes in the microbial communities, it is reasonable to conclude that the microbial composition and activity was ubiquitous in the Milwaukee area sites encompassed by this study.

\section{CONCLUSION}

This study was unable to detect large scale, consistent differences in bacterial or fungal community structure and microbial biomass along an urbanization gradient, despite using a variety of well-documented and optimized procedures. Although subtlevariances in microbial community profiles were observed within the urbanized landscapes, the microbial communities were largely redundant. Any significant differences observed in soil properties did not reflect large scale differences in microbial composition or biomass, which is likely attributed to the high levels of soil organic matter and carbon resources throughout the locations encompassed in this study. Therefore, because these soils appear to have the capacity to decompose organic matter equally within a similar geographic and climatic region, the impact of urbanization and landscape management practices does not appear to dramatically alter soil microbiology where parent material, soil-forming processes, and soil carbon resources are homogeneous.

\section{LITERATURE CITED}

Anderson, I.C., and J.W.G. Cairney. 2004. Diversity and ecology of soil fungal communities increased understanding through the application of molecular techniques. Environmental Microbiology 6(8):769-779.

Ayansina, A.D., and B.A. Oso. 2006. Effect of two commonly used herbicides on soil microflora at two different concentrations. African Journal of Biotechnology 5(2):129-132.

Balser, T.C. 2001. The impact of long-term nitrogen addition on microbial community composition in three Hawaiian forest soils. The Scientific World 1(2):500-504.

Blake, G.R., and K.H. Hartage. 1986. Bulk Density. pp. 363-375. In: A. Klute (Ed.). Methods of Soil Analysis. Part 1, second edition. Agronomy Monograph 9. ASA and SSSA, Madison, Wisconsin, U.S.

Clarke, K.R., and R.M. Warwick. 2001. Changes in Marine Communities: An Approach to Statistical Analysis and Interpretation, second edition. PRIMER-E Ltd, Plymouth, UK. 
Clarke, K.R., and R.N. Gorley. 2006. PRIMER v6. User Manual/ Tutorial. PRIMER-E, Plymouth, UK.

Crawl, P.J. (Ed.). 1999. Urban Soils: Applications and Practices. John Wiley and Sons, Inc., Hoboken, New Jersey, U.S.

Faeth, S.H., P.S. Warren, E. Shochat, and W.A. Marussich. 2005. Trophic Dynamics in Urban Communities. Bioscience 55(5):399-407.

Fantroussi, S.E., L. Verschuere, W. Verstraete, and E.M. Top. 1999. Effect of phenylurea herbicides on soil microbial communities estimated by analysis of 16 s gene fingerprints and communitylevel physiological profiles. Applied Environmental Microbiology 65(3):982-988.

Gardner, W.H. 1986. Water Content. pp. 493-541. In: A. Klute (Ed.). Methods of Soil Analysis. Part 1, second edition. Agronomy Monograph 9. ASA and SSSA, Madison, Wisconsin, U.S.

Gee, G.W., and J.W. Bauder. 1986. Particle-size analysis. pp. 383411. In: A. Klute (Ed.). Methods of Soil Analysis. Part 1, second edition. Agronomy Monograph 9. ASA and SSSA, Madison, Wisconsin, U.S.

Girvan, M.S., J. Bullimore, J.N. Pretty, A.M. Osborn, and A.S. Ball. 2003. Soil type is the primary determinant of the composition of the total and active bacterial communities in arable soils. Applied and Environmental Microbiology 69:1800-1809.

Goldfarb, K.C., U. Karaoz, C.A. Hanson, C.A. Santee, M.A. Bradford, K.K. Treseder, M.D. Wallenstein, and E.L. Brodie. 2011. Differential growth responses of soil bacterial taxa to carbon substrates of varying chemical recalcitrance. Frontiers in Microbiology 2:1-10.

Hackl, E., S. Zechmeister-Boltenstern, L. Bodrossy, and A. Sessetsch. 2004. Comparison of diversities and compositions of bacterial populations inhabiting natural forest soils. Applied and Environmental Microbiology 70(9):5057-5065.

Hall, S.J., B. Ahmed, P. Ortiz, R. Davies, R.A. Sponseller, and N.B. Grimm. 2009. Urbanization alters soil microbial functioning in the Sonoran desert. Ecosystems 12:654-671.

Hinojosa, M.B., J.A. Carreira, R. Garcia-Ruiz, and R.P. Dick. 2005. Microbial response to heavy metal-polluted soils: Community analysis from phospholipid-linked fatty acids and esterlinked fatty acids extracts. Journal of Environmental Quality 34:1789-1800.

Högberg, M.N., P. Högberg, and D.D. Myrold. 2007. Is microbial community composition in boreal forest soils determined by $\mathrm{pH}, \mathrm{C}$-to-N ratio, the trees, or all three? Oecologia 150:590-601.

Kalra, Y.P., and D.G. Maynard. 1991. Methods manual for forest soil and plant analysis. For. Can., Northwest Reg., North. For. Cent., Edmonton, Alberta. Inf. Rep. NOR-X-319.

Kaye, J.P., R.L. McCulley, and I.C. Burke. 2005. Carbon fluxes, nitrogen cycling, and soil microbial communities in adjacent urban, native, and agricultural systems. Global Change Biology 11:575-587.

Lauber, C.L., M.S. Strickland, M.A. Bradford, and N. Fierer. 2008. The influence of soil properties on the structure of bacterial and fungal communities across land-use types. Soil Biology \& Biochemistry 40:2407-2415.

Liu, W.T., T.L. Marsh, H. Cheng, and L.J. Forney. 1997. Characterization of microbial diversity by determining terminal restriction fragment length polymorphism of genes encoding 16s rRNA. Applied and Environmental Microbiology 63(11):4516-4522.

McDonnell, M.J., S.T.A. Pickett, P. Groffman, P. Bohlen, R.V. Poyat, W.C. Zipperer, R.W. Parmelee, M.M. Carreiro, and K. Medley. 1997. Ecosystem processes along an urban-to-rural gradient. Urban Ecosystems 1:21-36.
Newbound, M., L.T. Bennett, J. Tibbits, and S. Kasel. 2012. Soil chemical properties, rather than landscape context, influence woodland fungal communities along an urban-rural gradient. Austral Ecology 27:236-247.

Nowak, D.J., R.E. Hoehn III, D.E. Crane, J.C. Stevens, and J.T. Walton. 2007. Assessing urban forest effects and values: Philadelphia's urban forest. Northern Research Station Research Bulletin NRS-6. 22 pp.

Omar, S.A., M.A. Abdel-Sater, A.M. Khallil, and M.H. Abd-Alla. 1994. Growth and enzyme activities of fungi and bacteria in soil salinized with sodium chloride. Folia Microbiology 39(1):23-28.

Park S.J., Z. Cheng, H. Yang, E.E. Morris, M. Sutherland, B.B. McSpadden Gardener, and P.S. Grewal. 2010. Differences in soil chemical properties with distance to roads and age of development in urban areas. Urban Ecosystems 13:483-497.

Pavao-Zuckerman, M.A., and D.C. Coleman. 2007. Urbanization alters the functional composition, but not taxonomic diversity, of the soil nematode community. Applied Soil Ecology 35:329-339.

Pouyat, R.V., I.D. Yesilonis, J. Russell-Anelli, and N.K. Neerchal. 2007. Soil chemical and physical properties that differentiate urban land-use and cover types. Soil Science Society of America Journal 71(3):1010-1019.

Rees G.N., D.S. Baldwin, G.O. Watson, S. Perryman, and D.L. Nielsen. 2004. Ordination and significance testing of microbial community composition derived from terminal restriction fragment length polymorphisms: Application of multivariate statistics. Antonie van leeuwenhock 86:339-347.

Rietz, D.N., and R.J. Haynes. 2003. Effects of irrigation-induced salinity and sodicity on soil microbial activity. Soil Biology and Biochemistry 35(6):845-854.

Rousk J., P.C. Brookes, and E. Baath. 2009. Contrasting Soil pH effects on fungal and bacterial growth suggest functional redundancy in carbon mineralization. Applied and Environmental Microbiology 75(6):1589-1596.

Rousk J., E. Baath, P.C. Brookes, C.L. Lauber, C. Lozupone, J.G. Caporaso, R. Knight, and N. Fierer. 2010. Soil bacterial and fungal communities across a $\mathrm{pH}$ gradient in an arable soil. The ISME Journal.

Scharenbroch, B.C., J.E. Lloyd, and J.L. Johnson-Maynard. 2005. Distinguishing urban soils with physical, chemical, and biological properties. Pedobiologia 49:283-296.

Scharenbroch, B.C., and J.E. Lloyd. 2006. Particulate organic matter and soil nitrogen availability in urban landscapes. Arboriculture \& Urban Forestry 32(4):180-191.

Singh, B.K., N. Nunan, K.P. Ridgway, J. McNicol, J.P.W. Young, T.J. Daniell, J.L. Prosser, and P. Millard. 2008. Relationship between assemblages of mycorrhizal fungi and bacteria on grass roots. Environmental Microbiology 10:534-541.

Soil Survey Staff. Natural Resources Conservation Service, United States Department of Agriculture. Web Soil Survey. <http:// websoilsurvey.nrcs.usda.gov>

Thakuria, D., O. Schmidta, M. Siúrtáina, D. Egana, and F. Doohana. 2008. Importance of DNA quality in comparative soil microbial community structure analyses. Soil Biology and Biochemistry 40(6):1390-1403.

Waldrop, M.P., and M.K. Firestone. 2004. Microbial community utilization of recalcitrant and simple carbon compounds: Impacts of oak-woodland plant communities. Oecologia 138:275-284. 
Xu, HJ., S. Li, JQ. Su, S. Nie, V. Gibson, H. Li, and YG. Zhu. 2014. Does urbanization shape bacterial community composition in urban park soils? A case study in 16 representative Chinese cities based on the pyrosequencing method. FEMS Microbial Ecology 87:182-192.

Yang Y., C.D. Campbell, L. Clark, C.M. Cameron, and E. Paterson. 2006. Microbial indicators of heavy metal contamination in urban and rural soils. Chemosphere 63(11):1942-1952

Zak, D.R., W.E. Holmes, D.C. White, A.D. Peacock, and D. Tilman. 2003. Plant diversity, soil microbial communities, and ecosystem function: Are there any links? Ecology 84(8):2042-2050.

Zhang, L., Z. Xu, and B. Patel. 2009. An improved method for purifying genomic DNA from forest leaf litters and soil suitable for PCR. Journal of Soils and Sediments 9:261-266.

Zhou, J., B. Xia, D.S. Treves, L.Y. Wu, T.L. Marsh, R.V. O’Neill, A.V. Palumbo, and J.M. Tiedje. 2002. Spatial and resource factors influencing high microbial diversity in soil. Applied and Environmental Microbiology 68:326-334.

Keith N. Turnquist (corresponding author)

Wisconsin Cooperative Fishery Research Unit

College of Natural Resources

University of Wisconsin-Stevens Point

800 Reserve Street

Stevens Point, Wisconsin 54481, U.S.

kturnqui@uwsp.edu

Les P. Werner. Forestry

College of Natural Resources

University of Wisconsin-Stevens Point

800 Reserve Street

Stevens Point, Wisconsin 54481, U.S.

Brian L. Sloss

College of Natural Resources

University of Wisconsin-Stevens Point

800 Reserve Street

Stevens Point, Wisconsin 54481, U.S.

Résumé. Le processus d'urbanisation peut affecter la capacité des micro-organismes à fournir des éléments nutritifs aux plantes. Toutefois, tant la composition et la structure des communautés biologiques des sols, que l'étendue des variations au sein de ces communautés ne sont pas claires en milieu urbain. Par conséquent, l'information de base concernant l'impact des pratiques de gestion des sols en milieu urbain sur les communautés microbiennes de ces mêmes sols est essentielle afin d'améliorer la capacité des gestionnaires à gérer les sols urbains et les plantes qui y croissent. Cette étude a analysé les communautés microbiennes des sols de cinq terrains urbains aux usages variés et ce, en fonction de différents degrés d'urbanisation dans la région métropolitaine de Milwaukee dans létat du Wisconsin, États-Unis. Les objectifs étaient de 1) déterminer s'il existe des différences dans la composition des communautés bactériennes et fongiques, dans l'activité biologique et dans les propriétés physico-chimiques du sol dans les cinq différents types d'usage des sols urbains, et 2) déterminer si les différences dans les compositions bactériennes et fongiques se comparaient aux différences dans les propriétés physico-chimiques des sols. Il existe des différences significatives entre les sols longeant les rues et les sols des forêts dans la composition de la densité volumétrique, la matière organique du sol, le $\mathrm{pH}$, le magnésium, le sodium, l'azote total et le ratio $\mathrm{C}: \mathrm{N}$. La biomasse microbienne ne différait pas en fonction de l'usage des sols, et les différences dans la composition des communautés bactériennes et fongiques n'affectent qu'une petite partie du bassin microbien global. La décomposition de la litière foliaire transposée affichait une baisse significative dans le rapport $\mathrm{C}: \mathrm{N}$ sur une période de temps, mais on n'a observé aucune différence statistique selon les différents usages des sols. Les résultats affichaient un assemblage microbien hautement redondant, et suggèrent que dans les endroits présentant des niveaux adéquats de carbone dans le sol, et où la roche mère et les processus de formation du sol sont homogènes, l'urbanisation et l'aménagement paysager de surface ont moins d'impact que prévu sur la microbiologie du sol.

Zusammenfassung. Der Prozess der Urbanisierung könnte die Fähigkeit von Mikroorganismen zur Lieferung von Nährstoffen zur Pflanze verändern. Dennoch sind weder die Zusammensetzung noch die Struktur der bodenbiologischen Mikroorganismen und das Ausmaß der Variation innerhalb dieser Gemeinschaften in urbanen Gegenden verständlich. Daher sind die Basisinformationenbezüglich des Einflusses der Managementpraktiken von urbanen Flachen auf die bodenbiologischen Gemeinschaften wichtig, um die individuellen Fähigkeiten zur Unterhaltung von urbanen Böden und der Pflanzen, die darauf gedeihen, zu verbessern. Diese Studie untersucht bodenbiologische Gemeinschaften von Mikroorganismen in fünf verschiedenen Landnutzungsarten mit einem unterschiedlichen Grad an Urbanisierung in der Metropole Milwaukee, Wisconsin, U.S. Die Ziele sind: 1. Bestimmung, ob Unterschiede bestehen in der bakteriellen und fungalen Gemeinschaftszusammensetzung, biologische Aktivität und die bodenpysikalischen und -chemischen Umwelten in den unterschiedlichen fünf Landnutzungsbereichen; 2. Bestimmung, ob Unterschiede in der bakteriellen und fungalen Gemeinschaftszusammensetzung vergleichbar sind mit den bodenpysikalischen und -chemischen Charakteristika. Körperdichte, organische Masse, $\mathrm{pH}$, Magnesium, Natrium, totaler Stickstoff und C:N Verhältnis zeigten signifikante Unterschiede zwischen Straßen und Wäldern. Mikrobielle Biomasse zeigt keine Unterschiede zwischen den verschieden Landnutzungen und die Unterschiede in der bakteriellen und fungalen Gemeinschaftszusammensetzung reflektieren nur einen kleinen Anteil von dem gesamten mikrobiellen Pool. Die Zersetzung von transponierten Blattabfällen zeigten einen signifikanten Abfall im C:N Verhältnis über die Zeit, aber zwischen den verschiedenen Landnutzungen wurden keine statistischen Unterschiede beobachtet. Die Ergebnisse zeigen eine hohe redundante mikrobielle Gesellschaft und legen nahe, dass die Urbanisation und die Bewirtschaften der Landschaften in Bereichen mit adäquaten Anteilen von Kohlenstoff im Boden (und wo die Ausgangsmaterialien und der bodenformende Prozess homogen verläuft) einen geringeren Einfluss auf die Bodenbiologie haben als erwartet.

Resumen. El proceso de urbanización puede alterar la capacidad de los microorganismos para suministrar nutrientes a las plantas. Sin embargo, no está claro en las zonas urbanas tanto la composición y estructura de las comunidades biológicas del suelo, como el grado de variación dentro de estas comunidades. Por lo tanto, la información básica sobre el impacto de las prácticas de manejo de zonas urbanas en las comunidades microbianas del suelo es esencial para mejorar la capacidad de los individuos para manejar los suelos urbanos y las plantas que soportan. Este estudio examinó las comunidades microbianas del suelo en más de cinco usos de terrenos urbanos con diferentes grados de urbanización en el área metropolitana de Milwaukee, Wisconsin, Estados Unidos. Los objetivos fueron: 1) determinar si existen diferencias en 
la composición de la comunidad bacteriana y fúngica, actividad biológica y el medio ambiente físico y químico del suelo a través de cinco usos del suelo urbano, y 2) determinar si existen diferencias en las composiciones de bacterias y hongos en comparación con las diferencias en las características físicas y químicas del suelo. La densidad aparente, la materia orgánica del suelo, $\mathrm{pH}$, magnesio, sodio, nitrógeno total, y la relación $\mathrm{C}$ : $\mathrm{N}$ muestran diferencias significativas entre las calles y los bosques. La biomasa microbiana no difirió entre los usos del suelo, y las diferencias en la composición de la comunidad bacteriana y fúngica reflejan sólo una pequeña porción de la alberca microbiana total. La descomposición de hojarasca transpuesta mostró disminución significativa en la relación C: $\mathrm{N}$ en el tiempo, pero no se observaron diferencias estadísticas entre los usos del suelo observados. Los resultados muestran un conjunto microbiano muy redundante, y sugieren que en lugares con niveles adecuados de carbono en el suelo y donde el material parental y procesos de formación del suelo son homogéneos, la gestión del paisaje urbano tiene menos impacto de lo esperado en la microbiología del suelo. 